\title{
Fatty acid profile of an indigenous strain of Lentinus sajor-caju (Basidiomycota)
}

\author{
LATA $^{1 *(D)}$, Narender Singh ATRI ${ }^{2}$ \\ ${ }^{1}$ Department of Botany, Eternal University Baru Sahib, Sirmour, Himachal Pradesh 173101, India \\ ${ }^{2}$ Department of Botany, Punjabi University Patiala, Punjab 147002, India
}

\begin{abstract}
The aim of the present study was to investigate the fatty acid composition of an indigenous strain of Lentinus sajor-caju collected in the wild and cultivated under laboratory conditions. This edible mushroom is widely consumed in different parts of the world. The study revealed the presence of 26 fatty acids, including saturated fatty acids (SFA$27.69 \%$ ), monounsaturated fatty acids (MUFA-5.42\%), and polyunsaturated fatty acids (PUFA-65.06\%) in varying quantities ranging from $0.01 \%$ to $60.62 \%$. Amongst the estimated fatty acids, linoleic acid $(60.62 \%)$ was preponderantly present in comparison to all other fatty acids. Palmitic acid (17.6\%) was found to be the second and oleic acid (3.95\%) the third most abundant fatty acid in the fungus.
\end{abstract}

Keywords: Flame ionization detector (FID), gas chromatography (GC), Lentinus sajor-caju, monounsaturated fatty acids (MUFA), polyunsaturated fatty acids (PUFA), saturated fatty acids (SFA), sporophores

Article history. Submitted 2 June 2021. Revised 11 August 2021. Published 29 October 2021

Citation. Lata, Atri N.S. 2021. Fatty acid profile of an indigenous strain of Lentinus sajor-caju (Basidiomycota). Ukrainian Botanical Journal, 78(5): 327-334. https://doi.org/10.15407/ukrbotj78.05.327

*Corresponding author (e-mail: lg85.lataguleria@rediff.com)

\section{Introduction}

The sporophores of edible mushrooms are considered to be valuable health foods that are appreciated for their texture, flavour, nutritional properties, as well as for their therapeutic properties due to the effectiveness in preventing hypercholesterolemia, coronary atherosclerosis, for antitumor activities and immunomodulation. Mushrooms possess high amounts of proteins, vitamins, minerals, essential unsaturated fatty acids, and low proportions of fat content (Crisan, Sands, 1978; Tressl et al., 1982; Grosch, Wurzenberger, 1984). Fatty acids are carboxylic acids with long hydrocarbon chains which are either saturated or unsaturated. These are the major source of energy for the human beings and are reported to play a major role in tissue development and the absorption of the fat-soluble vitamins A, D, E, K and other food components, such as carotenoids.
Lentinus sajor-caju (Fr.) Fr. is an agaricoid basidiomycetous fungus belonging to the family Polyporaceae (Polyporales, Agaricomycetes). The edibility and culinary relevance of $L$. sajor-caju has been documented in the earlier literature published by many investigators from different countries including India, Malaysia, Philippines, Tanzania, Vietnam, etc. (Chin, 1981; Corner, 1981; Purkayastha, Chandra, 1985; Verma et al., 1995; Puttaraju et al., 2006; Kavishree et al., 2008; De Leon et al., 2012; Singdevsachan et al., 2013; Sharma, Atri, 2014; Afiukwa et al., 2015; Dulay et al., 2015; Gaur et al., 2016; Hussein et al., 2016; Reneses et al., 2016). As far as India is concerned, not much work has been done in this regard. In view of this, detailed investigation was carried out using the sporophores of L. sajor-caju produced from the indigenous culture of the species collected from the wild in order to study its nutritional and nutraceutical constituents, including the fatty acid profile presented in this article.

(C) 2021 Lata, N.S. Atri. Published by the M.G. Kholodny Institute of Botany, NAS of Ukraine. This is an open access article under the terms of the Creative Commons Attribution License (http://creativecommons.org/licenses/by/4.0/), which permits use, distribution, and reproduction in any medium, provided the original work is properly cited 


\section{Materials and Methods}

Fatty acids were estimated using gas chromatography with a flame ionization detector (GC-FID) following standard protocol given by Ranganna (1986).

Material. The sporophores produced during laboratory cultivation from the indigenous culture of Lentinus sajor-caju collected from the wild were used for investigation of its fatty acid profile. The culture has been deposited in the Microbial Type Culture Collection, Institute of Microbial Technology (IMTECH), Mohali, Punjab, under MTCC No. 10945.

Chemicals and reagents. All reagents and chemicals used for our analysis were of analytical grade. The fatty acid reference standard mixture of 37 fatty acids, methanol and sulphuric acid were obtained from SIGMA while n-hexane, petroleum ether, toluene and sodium sulphate were obtained from MERCK.

Standard preparation. For the calibration purpose, 37 fatty acids control reference standard was prepared.

Sample preparation. To cultivate $L$. sajor-caju, an indigenous culture raised in the laboratory through tissue culture technique was used. For cultivation, locally available ligno-cellulosic natural substrates, namely paddy straw, wheat straw, sawdust and wooden flakes, were used separately and in combination in the ratio of $1: 1: 1: 1$. For each substrate and their combinations used for cultivation, three polypropylene bags with 500 $\mathrm{g}$ substrate on dry weight basis were taken. Substrates of each such bag were soaked in water for at least two days. Excess of water was decanted off from the soaked substrate and filled in polythene bags followed by moist heat sterilization in an autoclave at $15 \mathrm{psi}$ (pound-force per square inch) pressure, for 1 hour at least twice before use, in order to make it free from any infection. Spawning of the substrate was done aseptically with $7-8 \%$ of the spawn prepared on wheat grains. The inoculated bags were incubated in the incubator at $33 \pm 1{ }^{\circ} \mathrm{C}$. Polythene covering was removed from the colonized substrates on complete colonization and which were then transferred to a cropping room maintained at $28 \pm 1{ }^{\circ} \mathrm{C}$ temperature and high relative humidity $(85 \%-90 \%)$. The required humidity was maintained in the cropping room with the help of a humidifier. The sporophores raised through cultivation under laboratory conditions were harvested and dried in a hot air drier at $45 \pm 1{ }^{\circ} \mathrm{C}$ (Atri et al., 2005).

For fat extraction, $100 \mathrm{~g}$ of mushroom powder prepared by crushing sporophores was soaked in n-hexane. The extracted fat was converted to methyl esters. For methylation, the extracted fat was mixed with a transmethylation mixture $(150 \mathrm{~mL}$ of methanol $+70 \mathrm{~mL}$ of toluene $+7.5 \mathrm{~mL}$ concentrated sulphuric acid) which was then kept in water bath under reflux for 90 minutes. Petroleum ether and ultra-pure water were added to it on cooling and the aqueous layer was collected. This was followed by repeated washing and addition of sodium sulphate. The clear ether layer so obtained was evaporated to dryness. Residue obtained was then dissolved in the petroleum ether and used for the fatty acid profile through gas chromatography.

Instrumentation. Fatty acid profiling was performed with Thermo Scientific Model Trace GC Ultra equipped with a HP-88 column $(100 \mathrm{~mm} \times 0.25 \mathrm{~mm} \times 0.20 \mu \mathrm{m})$, a flame ionization detector (FID), and a split injector. Oven temperature and injector temperature were maintained at $250{ }^{\circ} \mathrm{C}$ and $60-140{ }^{\circ} \mathrm{C}$, respectively. Helium gas was used as the mobile phase. For analysis, $1 \mu \mathrm{l}$ of control reference standard and the mushroom sample to be investigated were injected in the instrument. Fatty acid identification was done by comparing the relative retention time of an individual fatty acid. The peaks obtained in the sample chromatogram were compared with the standard chromatogram. Results are expressed in relative values $(\%)$.

\section{Results}

Mushroom samples of L. sajor-caju were analysed and quantified for the presence of 37 fatty acids, out of which 26 fatty acids were observed in L. sajor-caju. Fatty acid composition of the mushroom revealed the presence of saturated fatty acids (SFA), monounsaturated fatty acids (MUFA), polyunsaturated fatty acids (PUFA), and trans-fatty acids (TFA) in varying quantities ranging from $0.01 \%$ to $60.62 \%$. The fatty acid composition, the amount (\%) of the individual component obtained and chromatographic spectral data obtained for $L$. sajorcaju are summarized in Tables 1,2 and depicted in chromatogram Figs 1, 2.

The carbon chain length of saturated fatty acids ranged from 4 to 24 and content from $0.09 \%$ to $17.6 \%$. Some of the documented saturated fatty acids in the mushroom which were present in high proportion include palmitic acid (17.6\%), pentadecylic acid (2.73\%), stearic acid (1.75\%), tricosylic acid (1.72\%) and margaric acid $(1.49 \%)$, while those determined in smaller proportion were myristic acid $(0.72 \%)$, undecylic acid $(0.42 \%)$, lignoceric acid $(0.42 \%)$, lauric acid $(0.40 \%)$, behenic acid $(0.35 \%)$ and caprylic acid $(0.09 \%)$. Other fatty acids, 


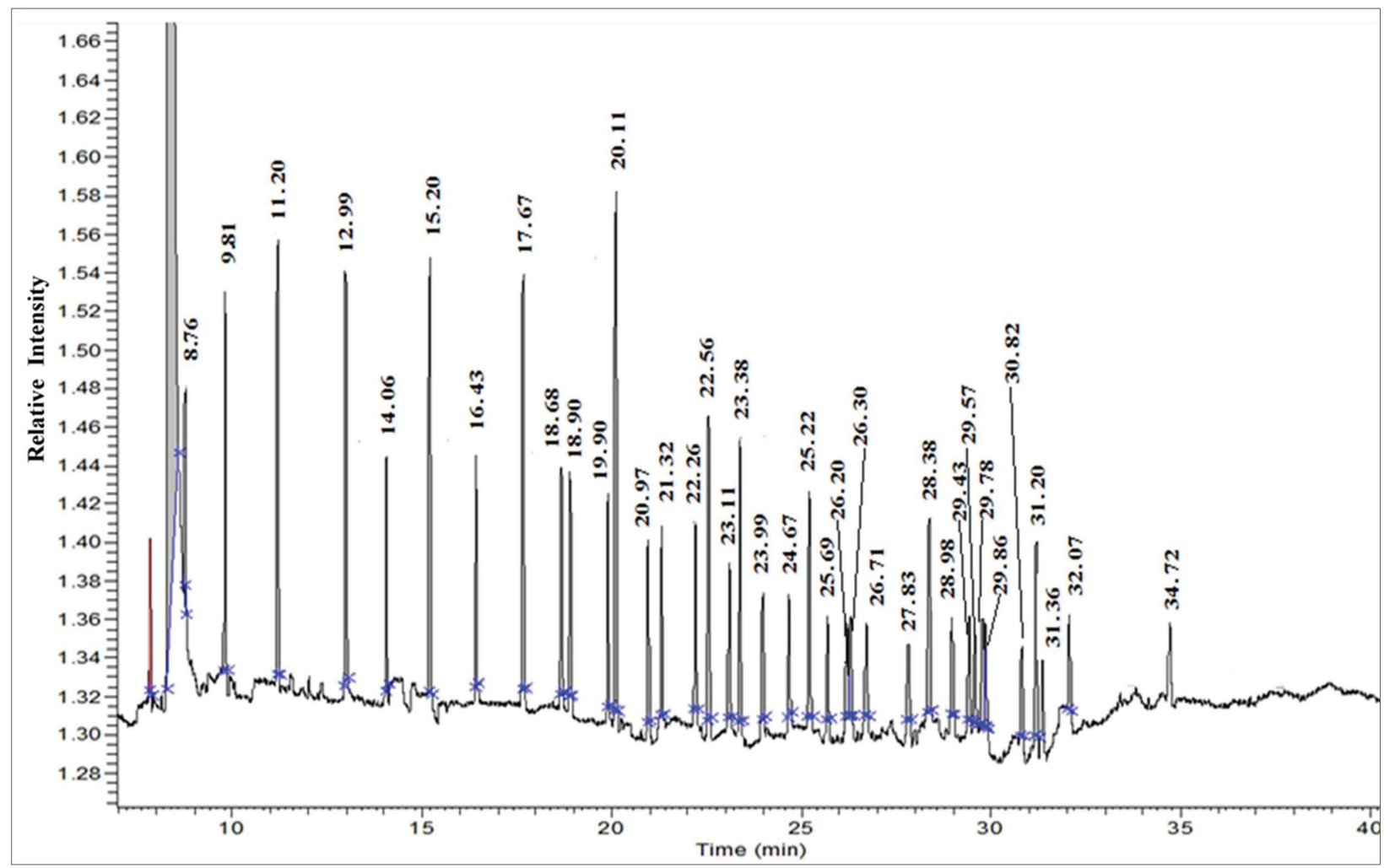

Fig. 1. Gas chromatography chromatogram of fatty acid standards

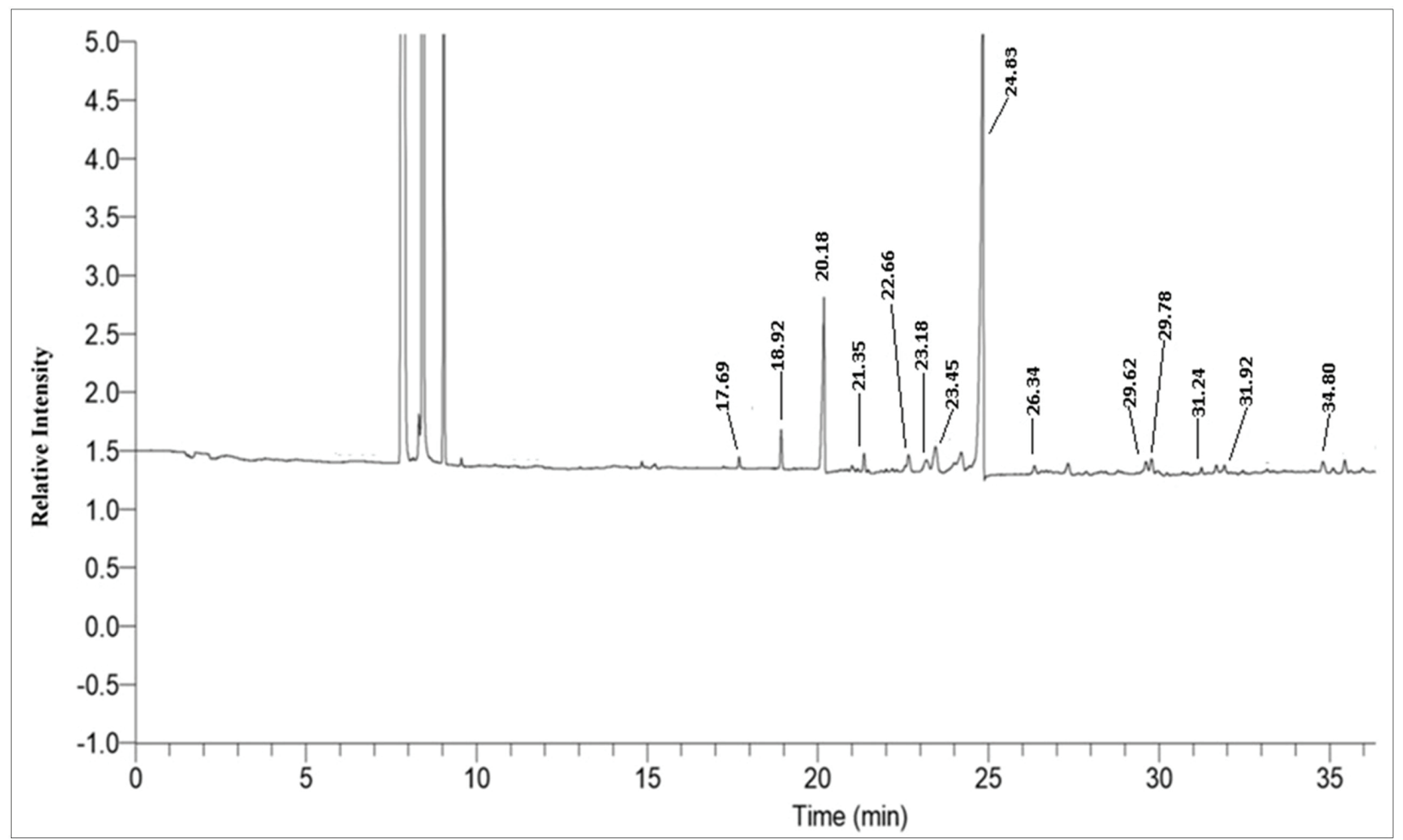

Fig. 2. Gas chromatography chromatogram of fatty acid composition of Lentinus sajor-caju 
such as butyric acid, caproic acid, capric acid, tridecylic acid, arachidic acid and heneicosylic acid, were not detected in L. sajor-caju. In all, $27.69 \%$ saturated fatty acids were accounted of the total fatty acids.

For comparison, the quantity of unsaturated fatty acids ranged from $0.01 \%$ to $60.62 \%$ with the carbon chain length extending from 14 to 24 . Amongst the evaluated fatty acids in the mushroom, the essential fatty acid, linoleic acid $(60.62 \%)$, was recorded in substantially high proportions.

Amongst the monounsaturated fatty acids, oleic acid (3.95\%) was observed in higher proportion followed by nervonic acid $(0.94 \%)$ and palmitoleic acid $(0.39 \%)$. Some of the monounsaturated fatty acids, including myristoleic acid, cis-10-pentadecanoic acid and cis-11eicosenoic acid, were not detected in the sporophores. On overall basis, monounsaturated fatty acids accounted for $5.42 \%$ of the total fatty acids were present in the evaluated samples.

Lentinus sajor-caju contained high proportions of polyunsaturated fatty acid content because of the presence of the highest quantity of linoleic acid (60.62\%). Polyunsaturated fatty acids accounted for $65.06 \%$ of the
Table 1. Saturated fatty acid composition of Lentinus sajor-caju

\begin{tabular}{|c|c|c|c|c|}
\hline $\begin{array}{c}\text { S. } \\
\text { no. }\end{array}$ & Fatty acids & $\begin{array}{l}\text { Carbon } \\
\text { number }\end{array}$ & $\begin{array}{c}\text { Retention } \\
\text { time } \\
\text { (minutes) }\end{array}$ & $\begin{array}{c}\text { Amount } \\
\text { of fatty } \\
\text { acids, } \\
\text { total } \\
\text { content } \\
(\%)\end{array}$ \\
\hline 1 & Butyric/Butanoic acid & $\mathrm{C} 4: 0$ & - & ND \\
\hline 2 & Caproic/Hexanoic acid & C6:0 & - & ND \\
\hline 3 & Caprylic/Octanoic acid & $\mathrm{C} 8: 0$ & $11: 23$ & 0.09 \\
\hline 4 & Capric/Decanoic acid & C10:0 & - & ND \\
\hline 5 & Undecylic/Undecanoic acid & C11:0 & 14:04 & 0.42 \\
\hline 6 & Lauric/Dodecanoic acid & $\mathrm{C} 12: 0$ & $15: 23$ & 0.40 \\
\hline 7 & Tridecylic/Tridecanoic acid & $\mathrm{C} 13: 0$ & - & ND \\
\hline 8 & Myristic/Tetradecanoic acid & C14:0 & $17: 69$ & 0.72 \\
\hline 9 & Pentadecylic/Pentadecanoic acid & $\mathrm{C} 15: 0$ & 18:92 & 2.73 \\
\hline 10 & Palmitic/Hexadecanoic acid & C $16: 0$ & $20: 18$ & 17.6 \\
\hline 11 & Margaric/Heptadecanoic acid & C 17:0 & $21: 35$ & 1.49 \\
\hline 12 & Stearic/Octadecanoic acid & C $18: 0$ & $22: 66$ & 1.75 \\
\hline 13 & Arachidic/Eicosanoic acid & C 20:0 & - & ND \\
\hline 14 & Heneicosylic/Heneicosanoic acid & C 21:0 & - & ND \\
\hline 15 & Behenic/Docosanoic acid & C 22:0 & $28: 31$ & 0.35 \\
\hline 16 & Tricosylic/Tricosanoic acid & C 23:0 & $29: 78$ & 1.72 \\
\hline 17 & Lignoceric/Tetracosanoic acid & $\mathrm{C} 24: 0$ & $31: 24$ & 0.42 \\
\hline \multicolumn{4}{|c|}{ Total saturated fatty acids } & 27.69 \\
\hline
\end{tabular}

Table 2. Unsaturated and trans fatty acid composition of Lentinus sajor-caju

\begin{tabular}{|c|c|c|c|c|c|}
\hline S. no. & Fatty acid & $\begin{array}{l}\text { Carbon } \\
\text { number }\end{array}$ & Omega $(\omega)$ type & $\begin{array}{c}\text { Retention } \\
\text { time (minutes) }\end{array}$ & $\begin{array}{c}\text { Amount of fatty acids, total } \\
\text { content }(\%)\end{array}$ \\
\hline 1 & Myristoleic acid & C14:1 & 7 & - & ND \\
\hline 3 & Palmitoleic acid & $\mathrm{C} 16: 1$ & 7 & 21:00 & 0.39 \\
\hline 4 & Cis-10-heptadecanoic acid & $\mathrm{C} 17: 1$ & 7 & $22: 18$ & 0.13 \\
\hline 7 & Erucic acid & $\mathrm{C} 22: 1$ & 9 & $29: 35$ & 0.01 \\
\hline 8 & Nervonic acid & $\mathrm{C} 24: 1$ & 9 & $31: 92$ & 0.94 \\
\hline \multicolumn{5}{|c|}{ Total Monounsaturated Fatty Acids } & 5.42 \\
\hline \multicolumn{6}{|c|}{ Polyunsaturated fatty acids } \\
\hline 1 & $\alpha$-Linolenic acid & C18:3 & 3 & $26: 34$ & 0.87 \\
\hline 6 & $\gamma$-Linolenic acid & $\mathrm{C} 18: 3$ & 6 & - & ND \\
\hline 7 & Cis-11,14-eicosadienoic acid & $\mathrm{C} 20: 2$ & 6 & $27: 87$ & 0.30 \\
\hline 8 & Cis-8,11,14-eicosatrienoic acid & $\mathrm{C} 20: 3$ & 6 & $28: 89$ & 0.17 \\
\hline 9 & Arachidonic acid & $\mathrm{C} 20: 4$ & 6 & - & ND \\
\hline 10 & Cis-13,16-docosadienoic acid & $\mathrm{C} 22: 2$ & 6 & $30: 72$ & 0.25 \\
\hline \multicolumn{5}{|c|}{ Total Polyunsaturated fatty acids } & 65.06 \\
\hline \multicolumn{6}{|c|}{ Trans fatty acids } \\
\hline 1 & Elaidic acid & C18:1 & 9 & $23: 18$ & 1.17 \\
\hline 2 & Linoelaidic acid & C18:2 & 6 & $23: 99$ & 0.66 \\
\hline \multicolumn{5}{|c|}{ Total Trans fatty acids } & 1.83 \\
\hline
\end{tabular}


total fatty acids were found in the evaluated mushroom samples. In addition to linoleic acid, cis-11,14,17eicosatrienoic acid (1.68\%), cis-4,7,10,13,16,19docosahexaenoic acid $(1.05 \%)$ and $\alpha$-linolenic acid $(0.87 \%)$ were the other polyunsaturated fatty acids documented in the sporophores. As compared, cis-11,14eicosadienoic acid $(0.30 \%)$; cis-13,16-docosadienoic acid $(0.25 \%)$, cis- $8,11,14$-eicosatrienoic acid $(0.17 \%)$ and cis-5,8,11,14,17-eicosapentaeoic acid $(0.12 \%)$ were recorded to be present in traces while $\gamma$-linolenic acid and arachidonic acid were not detected in the studied mushroom. Elaidic acid (1.17\%) and linoelaidic acid $(0.66 \%)$ are the trans fatty acids which were also recorded during the estimation of fatty acids of $L$. sajor-caju.

\section{Discussion}

In the cultivated sporophores of $L$. sajor-caju, saturated fatty acids accounted for $27.69 \%$ of the total fatty acids content. Kavishree et al. (2008), while working on 23 wild mushroom fruiting bodies, documented $20 \%$ total saturated fatty acid content in L. sajor-caju, 30.6\% in L. squarrosulus Mont., 25.1\% in Pleurotus djamor (Rumph. ex Fr.) Boedijn and 27.1\% in P. sajor-caju which is almost comparable to the amount of saturated fatty acids documented in the presently evaluated samples. In cultivated sporophores of Lentinus squarrosulus SQW (27.43\%), L. squarrosulus LSF (25.78\%), Pleurotus ostreatus EM-I (21.87\%), P. sajor-caju (26.62\%), and naturally growing $P$. tuber-regium (Fr.) Singer (42.19\%), excepting P. tuber-regium, comparable proportion of total saturated fatty acid are reported by Obodai et al. (2014). While investigated the wild fruiting bodies of Lentinus connatus Berk. and L. cladopus Lév., Sharma and Atri (2014) recorded $27.05 \%$ and $27.76 \%$ of saturated fatty acid in these species, respectively. However, much higher amounts of total saturated fatty acid were reported by Sharma and Atri (2014) in the naturally growing L. sajorcaju (53.89\%), L. torulosus (Pers.) Lloyd (56.8\%) and L. squarrosulus (57.36\%) as compared to the presently analysed specimens of $L$. sajor-caju.

The palmitic acid content in the investigated specimens of $L$. sajor-caju (17.6\%) is almost comparable to the proportion of this fatty acid reported in L. sajorcaju (15.4\%), L. squarrosulus (16.6\%), Pleurotus djamor (15.8\%), and P. sajor-caju (13.9\%) by Kavishree et al. (2008). Obodai et al. (2014) also reported 18.04\% palmitic acid in L. squarrosulus LSF, $19.62 \%$ in L. squarrosulus
SQW, $17.84 \%$ in P. sajor-caju, $14.31 \%$ in P. ostreatus EM-I and $21.19 \%$ in $P$. tuber-regium, which is also almost comparable to the amount of this fatty acid that we documented in the evaluated samples of $L$. sajor-caju. Palmitic acid has been reported as the integral part of wild sporophores of L. sajor-caju (41.29\%), L. torulosus (41.83\%), L. squarrosulus $(45.13 \%)$, L. cladopus $(22.79 \%)$ and L. connatus (14.25\%) by Sharma and Atri (2014). From this it is apparent that in comparison to the wild samples $(41.29 \%)$, the amount of palmitic acid in the cultivated samples $(17.6 \%)$ evaluated presently is much lower than half of the amount in the wild samples. Ravikrishnan et al. (2015) reported 20\% palmitic acid in naturally growing L. polychrous Lév. While working with wild $L$. squarrosulus, slightly higher amount of palmitic acid $(18.89 \mathrm{mg} / 100 \mathrm{~g})$ was reported by Ghate and Sridhar (2019) and much less percentage $(4.55 \%)$ of the same fatty acid was reported by Manjunathan et al. (2017) in L. tuber-regium cultivated in the laboratory. Roy et al. (2020) documented $10.74 \%$ palmitic acid in naturally growing L. squarrosulus. Palmitic acid is reported to possess significant atherogenic and thrombogenic potential (Tvrzicka et al., 2011).

Substantially higher percentage of monounsaturated fatty acid has been determined by Kavishree et al. (2008) in Lentinus sajor-caju (25.1\%), Pleurotus djamor (29.4\%) and P. sajor-caju (19.1\%) in comparison to the presently investigated sample of $L$. sajor-caju; however, Obodai et al. (2014) reported almost comparable amount of MUFA in L. squarrosulus (6.8\%). Total monounsaturated fatty acid content in the presently investigated mushroom is on the lower $(5.42 \%)$ side in comparison to the proportion of monounsaturated fatty acid revealed in L. squarrosulus SQW (8.75\%), L. squarrosulus LSF (9.36\%), Pleurotus tuber-regium (24.07\%), P. ostreatus EM-I (18.92\%) and P. sajor-caju $(24.21 \%)$ by Obodai et al. (2014). Sharma and Atri (2014) also detected high amount of total monounsaturated fatty acid content in the wild samples of L. sajor-caju $(16.27 \%), L$. connatus (32.72\%), L. torulosus (17.93\%), L. cladopus $(67.35 \%)$ and L. squarrosulus (27.1\%) in comparison to the presently evaluated sample of $L$. sajor-caju cultivated in the laboratory.

Oleic acid (3.95\%) was found to be the most abundant monounsaturated fatty acid in the presently investigated mushroom specimens; it is reported to have therapeutic importance in decreasing the concentration of triacylglycerols (TAG), LDL-cholesterol and increasing the concentration of HDL-cholesterol and regulating 
insulin sensitivity. Oleic acid was also found to influence the anti-inflammatory response and reported to possess a protective role in carcinogenesis (Tvrzicka et al., 2011). However, its total proportion in the presently evaluated sample is on the lower side in comparison to its amount documented in Lentinus sajor-caju (23.5\%), L. squarrosulus (5.8\%), Pleurotus djamor (29.4\%) and P.sajor-caju (19.1\%) by Kavishree etal.(2008). Oleic acid was reported to occur in high amount in L. squarrosulus SQW (7.89\%), L. squarrosulus LSF (8.67\%), Pleurotus tuber-regium (21.21\%), P. ostreatus EM-I (18.30\%) and P. sajor-caju $(22.62 \%)$ by Obodai et al. (2014). While working with different wild sporophores of Lentinus species, much higher percentage of oleic acid has been reported in L. sajor-caju (13.9\%), L. connatus (23.38\%), L. torulosus $(13.56 \%)$, L. cladopus $(47.87 \%)$ and L. squarrosulus (23.38\%) by Sharma and Atri (2014). Ravikrishnan et al. (2015) also recorded high percentage (18.50\%) of oleic acid in L. polychrous. Oleic acid was documented in slightly high amount in L. tuber-regium (5.98\%) and L. squarrosulus (5.27\%) by Manjunathan et al. (2017) and Adeoye-Isijola et al. (2018), respectively.

Nervonic acid is the second most abundant $(0.94 \%)$ monounsaturated fatty acid presently recorded in L. sajor-caju. This is an important monounsaturated fatty acid reported to be involved in the biosynthesis of nerve cell myelin and preventing disorders such as adrenoleukodystrophy and multiple sclerosis in elderly people (Sargent et al., 1994; Nakalembe, Kabasa, 2013).

Lentinus sajor-caju has been evaluated to contain substantially high $(65.06 \%)$ proportion of polyunsaturated fatty acid in comparison to the other edible species, including L. sajor-caju (54.9\%), L. squarrosulus (62.9\%), Pleurotus djamor (45.5\%) and P. sajor-caju (53.8\%) by Kavishree et al., (2008). In the presently investigated mushroom samples, the net amount of polyunsaturated fatty acid $(65.06 \%)$ is much on the higher side in comparison to proportion of saturated fatty acid $(27.69 \%)$ and monounsaturated fatty acid (5.42\%) evaluated. Similar trend has been documented by Obodai et al. (2014) for Lentinus squarrosulus SQW (63.62\%), L. squarrosulus LSF (64.87\%), Pleurotus ostreatus EM-I (59.21\%), P. sajor-caju (49.17\%) and P. tuberregium (33.75\%). Sharma and Atri (2014) reported very low proportion of polyunsaturated fatty acid in the wild samples of Lentinus sajor-caju (1.31\%), L. connatus $(0.70 \%)$, L. torulosus $(1.3 \%)$, L. cladopus $(0.76 \%)$ and L. squarrosulus $(1.45 \%)$ in comparison to the presently investigated mushroom cultivated under laboratory conditions. From the therapeutic point of view, n-3 and n-6 polyunsaturated fatty acid, mainly linoleic acid, linolenic acid, cis-5,8,11,14,17-eicosapentaeoic acid and cis-4,7,10,13,16,19-docosahexaenoic acid (DHA), are known to modify membrane fluidity and thickness, regulate enzymes involved in lipid metabolism, exert anti-inflammatory effects on asthma, inflammatory bowel disease, rheumatoid arthritis, etc. (FAO, 2010). One of the polyunsaturated fatty acid, cis-4,7,10,13,16,19docosahexaenoic acid (DHA), has been reported to prevent cardiovascular disease and play critical role in neurogenesis, neurite growth, neuronal integrity, gene expression in the brain, synapse formation and function, glucose transport, cognitive development and learning ability (Norris et al., 2013).

The proportion of linoleic acid observed during the present study in L. sajor-caju is much on the higher side $(60.62 \%)$ in comparison to its amount reported in L. squarrosulus (37.29\%) by Ghate and Sridhar (2019) and in L. sajor-caju (54.9\%), Pleurotus djamor (45.5\%) and P. sajor-caju (53.8\%) by Kavishree et al. (2008). Obodai et al. (2014), while investigating some of the edible species of Pleurotus and Lentinus, detected high amount of linoleic acid in L. squarrosulus SQW (62.41\%), L. squarrosulus LSF (63.64\%), which is almost comparable to the presently investigated mushroom. In comparison, Ravikrishnan et al. (2015), Manjunathan et al. (2017), Adeoye-Isijola et al. (2018) and Roy et al. (2020) reported much less amount of linoleic acid in Lentinus polychrous $(25.30 \%)$, L. tuber-regium (7.44\%), L. squarrosulus SQW (37.29\%), L. squarrosulus LSF (24.21\%), respectively. Linoleic acid is known to act as a precursor of alcohol in fungi (1-octen-3-ol) and is one of the principal aromatic compounds in most fungi contributing to mushroom flavour (Maga, 1981). It is also reported as a potential cytotoxic agent against HeLa cell possessing antibacterial activity as well (Lee et al., 2002; Mei et al., 2006).

\section{Conclusion}

The results revealed that the cultivated sporophores of Lentinus sajor-caju are quite rich in essential fatty acids and unsaturated fatty acids, with linoleic acid, oleic acid and palmitic acid being present in substantial amounts. It also possesses higher amounts of unsaturated fatty acids in comparison to saturated fatty acids, which is quite significant from a nutritional standpoint. Therefore, it can form an important constituent of the human diet. 


\section{Acknowledgement}

The authors are grateful to the Head Department of Botany, Punjabi University, Patiala, Punjab, India for providing laboratory facilities.

The work was funded by the University Grants Commission with a grant under the DRS Phase - III (SAP) Program. The senior author is also indebted to the University Grants Commission for the award of fellowship under the UGC-BSR scheme.

\section{References}

Afiukwa C.A., Ebem E.C., Igwe D.O. 2015. Characterization of the proximate and amino acid composition of edible wild mushroom species in Abakaliki, Nigeria. AASCIT Journal of Biosciences, 1: 20-25.

Atri N.S., Kaur A., Kour H. 2005. Wild mushrooms collection and identification. In: Frontiers in Mushroom Biotechnology. Eds R.D. Rai, R.C. Upadhyay, S.R. Sharma. Chambaghat, Solan: NRCM, pp. 9-26.

Adeoye-Isijola M.O., Olajuyigbe O.O., Jonathan S.G., Coopoosamy R.M. 2018. Bioactive compounds in ethanol extract of Lentinus squarrosulus Mont. - a Nigerian medicinal macrofungus. African Journal of Traditional Complementary and Alternative Medicines, 15(2): 42-50. https://doi.org/10.21010/AJTCAMV15I2.6

Chin F.H. 1981. Edible and poisonous fungi from the forest of Sarawak. Part 1. Sarawak Mushroom Journal, 50: 211-225.

Corner E.J.H. 1981. The agaric genera Lentinus, Panus and Pleurotus, with particular references to Malaysian species. Nova Hedwigia Beihefte, 69: 1-169.

Crisan E.V., Sands A. 1978. Nutritional value. In: The biology and cultivation of edible fungi. Eds S.T. Chang, W.A. Hayes. New York Academic Press, pp. 727-793.

De Leon A.M., Reyes R.G., dela Cruz T.E.E. 2012. An ethnomycological survey of macrofungi utilized by Aeta Communities in Central Luzon, Philippines. Mycosphere, 3(2): 251-259. https://doi.org/10.5943/mycosphere/3/2/9

Dulay R.M.R., Flores K.S., Tiniola R.C., Marquez D.H.H., Cruz A.G.D., Kalaw S.P., Reyes R.G. 2015. Mycelial biomass production and antioxidant activity of Lentinus tigrinus and Lentinus sajor-caju in indigenous liquid culture. Mycosphere, 6(6): 659-666. https://doi. org/10.5943/mycosphere/6/6/2

FAO. 2010. Fats and fatty acids in human nutrition: Report of an expert consultation. Rome: Food and agricultural organization of the United Nations. FAO Food and Nutrition Paper, 91: 1-166.

Gaur T., Rao P.B., Kushwaha K.P.S. 2016. Nutritional and anti-nutritional components of some selected edible mushroom species. Indian Journal of Natural Products and Resources, 7(2): 155-161.
Ghate S.D., Sridhar K.R. 2019. Nutritional attributes of two wild mushrooms of south western India. In: Advances in Macrofungi: Diversity, Ecology and Biotechnology. Eds K.R. Sridhar, S.K. Deshmukh. Boca Raton: CRC Press, pp. 105-120.

Grosch W., Wurzenberger M. 1984. Enzymic formation of 1-ovten-3-ol in mushroom. Developments in Food Science, 10: $253-259$.

Hussein J.M., Tibuhwa D.D., Mshandete A.M., Kivaisi A.K. 2016. Successful domestication of Lentinus sajor-caju from an indigenous forest in Tanzania. Journal of Applied Biosciences, 108: 10500-10506. https://doi.org/10.4314/ jab.v108i1.4

Kavishree S., Hemavathy J., Lokesh B.R., Shashi Rekha M.N., Rajarathnam S. 2008. Fat and fatty acids of Indian edible mushrooms. Food Chemistry, 106: 597-602. https://doi. org/10.1016/j.foodchem.2007.06.018

Lee J.Y., Kim Y.S., Shin D.H. 2002. Antimicrobial effects of linoleic acid and monoglyceride against Bacillus cereus and Staphylococcus aureus. Journal of Agriculture and Food Chemistry, 50: 2193-2199. https://doi.org/10.1021/ if011175a

Maga J.A. 1981. Mushroom flavor. Journal of Agriculture and Food Chemistry, 29: 1-4.

Manjunathan J., Gowri S.S., Vennila N., Ezhilarasu A., Kaviyarasan V. 2017. Amino acid and fatty acid composition of indigenously cultivated edible mushroom Lentinus tuber-regium VKJM24 (HM060586). International Journal of Pharma Research Health Science, 5(5): 1886-1890.

Mei W., Dai H., Xu J. 2006. Composition and cytotoxic activity of the organic acids from Gracilaria lemaneiformis. Zhong Guo. Haiyang Yaowu, 25: 45-47.

Nakalembe I., Kabasa J.D. 2013. Fatty and amino acids composition of selected wild edible mushrooms of Bunyoro Sub-Region, Uganda. African Journal of Food Agriculture, Nutrition and Development, 13: 7225-7241. https://doi.org/10.18697/ajfand.56.11945

Norris R.G., Fischer M.H. 2013. The role of essential fatty acids in human health. Journal of Evidence-Based Complementary \& Alternative Medicine, 18(4): 268-289. https://doi.org/10.1177/2156587213488788

Obodai M., Isabel C.F.R.F., Angela F., Lillian B., Deborah L.N.M., Matilda D., Arailde F.U., Juanita P., Richard K.T. 2014. Evaluation of the chemical and antioxidant properties of wild and cultivated mushrooms of Ghana. Molecules, 19: 19532-19548. https://doi. org/10.3390/molecules191219532

Purkayastha R.P., Chandra A. 1985. Manual of Indian Edible Mushrooms. New Delhi: Jagmander Book Agency.

Puttaraju N.G., Venkateshaiah S.U., Dharmesh S.M., Nanjarajurs S.M., Somasundaram R. 2006. Antioxidant activity of indigenous edible mushrooms. Journal of Agriculture and Food Chemistry, 54: 9764-9772. https:// doi.org/10.1021/jf0615707

Ranganna S. 1986. Handbook of Analysis and Quality Control for Fruit and Vegetable Products. $2^{\text {nd }}$ ed. New Delhi: Tata McGraw Hill Publishing Company Limited, 1111 pp. 
Ravikrishnan V., Naik P., Ganesh S., Rajashekhar M. 2015. Profile of mushroom Lentinus polychrous Lev. from Western Ghats, Southern India. International Journal of Plant Animal Environmental Science, 5: 278-281.

Reneses M.A.M., Dulay R.M.R., De Leon A.M. 2016. Proximate nutritive composition and teratogenic effect of Lentinus sajor-caju collected from Banaue, Ifugao Province, Philippines. International Journal of Biology, Pharmacy and Allied Sciences, 5(7): 1771-1786.

Roy R.D., Kandagalla S., Krishnappa M. 2020. Exploring the ethnomycological potential of Lentinus squarrosulus Mont. through GC-MS and chemo informatics tools. Mycology, 11(1): 78-89. https://doi.org/10.1080/2150120 3.2019.1707724

Sargent J.R., Coupland K., Wilson R. 1994. Nervonic acid and demyelinating disease. Medical Hypothesis, 42: 237-242.

Sharma S.K., Atri N.S. 2014. Nutraceutical composition of wild species of genus Lentinus Fr. from Northern India. Current Research in Environmental \& Applied Mycology, 4(1): 11-32. https://doi.org/10.5943/cream/4/1/2
Singdevsachan S.K., Patra J.K., Thatoi H. 2013. Nutritional and bioactive potential of two wild edible mushrooms (Lentinus sajor-caju and Lentinus torulosus) from Similipal Biosphere Reserve, India. Food Science Biotechnology, 22(1): 137-145. https://doi.org/10.1007/ s10068-013-0019-7

Tressl R., Bahri D., Engel K.H. 1982. Formation of eight carbon and then ten carbon components in mushrooms (Agaricus campestris). Journal of Agriculture and Food Chemistry, 30: 89-93. https://doi.org/10.1021/ jf00109a019

Tvrzicka E., Kremmyda L.S., Stankova B., Zak A. 2011. Fatty acids as bio compounds: their role in human metabolism, health and disease - a review. Part 1: classification, dietary sources and biological function. Biomedical Papers, 155(2): 117-130.

Verma R.N., Singh B.G., Singh S.M. 1995. Mushroom flora of North Eastern Hills. In: Advances in Horticulture. Eds K.L. Chadha, S.R. Sharma. New Delhi: S.R. Molhotra Publishers House, pp. 329-349.

Recommended for publication by M.M. Sukhomlyn

Лата, Атрі Н.С. Профіль жирних кислот автохтонного штаму Lentinus sajor-caju (Basidiomycota). Украӥнський ботанічний журнал, 78(5): 327-334. https://doi.org/10.15407/ukrbotj78.05.327

Кафедра ботаніки, Вічний університет Бару Сахіб, Сірмур, Хімачал-Прадеш 173101, Індія: Лата. Кафедра ботаніки, Пенджабський університет Патіала, Пенджаб 147002, Індія: Н.С. Атрі.

Реферат. Метою цього дослідження було встановити склад жирних кислот їстівного гриба Lentinus sajorcaju, який широко споживається у світі, на прикладі вирощеного в культурі автохтонного штаму природного походження. Нами встановлено наявність 26 жирних кислот, включаючи насичені жирні кислоти (SFA-27,69\%), мононенасичені (MUFA-5,42\%) і поліненасичені жирні кислоти (PUFA-65,06\%) у різній кількості в межах від 0,01\% до 60,62\%. Виявлено, що серед усіх досліджених жирних кислот переважала лінолева кислота (60,62\%), а пальмітинова $(17,6 \%)$ та олеїнова $(3,95 \%)$ кислоти були відповідно другою і третьою за їхнім вмістом у цього гриба.

Ключові слова. Lentinus sajor-caju, газова хроматографія, мононенасичені жирні кислоти, насичені жирні кислоти, плодові тіла, поліненасичені жирні кислоти, полум'яно-іонізаційний детектор 